\title{
Relationship between ABO Blood Groups and Lipid Profile Level in Healthy Adult Residents in Port Harcourt Metropolis, Nigeria
}

\author{
${ }^{* 1}$ BARTIMAEUS, ES; WARIBO, ${ }^{2} \mathrm{HA}$ \\ ${ }^{1}$ Department of Medical Laboratory Science, Rivers State University, Port Harcourt, Nigeria \\ ${ }^{2}$ Department of Medical Laboratory Science, Rivers State School of Health Technology, \\ Rumueme, Port Harcourt, Nigeria \\ *Corresponding Author: Department of Medical Laboratory Science, Rivers State University, Port Harcourt, Nigeria \\ E-mail: ebbyagana@gmail.com. Phone: +2348033410302
}

\begin{abstract}
A multitude of risk factors are responsible for development of cardiovascular diseases (CVDs) and association of cardiovascular disease risk factors with the $\mathrm{ABO}$ blood antigens is increasingly being reported. Thus, this study was designed to investigate the relationship between $\mathrm{ABO}$ blood groups and lipoprotein profiles of apparently 150 healthy adult patients attending Braithwaite Memorial Specialist Hospital, Port Harcourt, Nigeria following due consent to participate in the study. The serum TC, HDL-C, LDL-C and VLDL-C levels were determined by standard methods. ABO blood grouping was carried out by standard tile technique. Results show that the mean of the TC and LDL-C of most of the subjects in all the blood groups appeared desirable $(<5.81 \mathrm{mmol} / \mathrm{L}$ and $<3.37 \mathrm{mmol} / \mathrm{L}$ ) respectively in both males and females. HDL-C was deficient in all blood groups both in males and females while the triglycerides level in the subjects was desirable $(<2.83 \mathrm{mmol} / \mathrm{L})$. While significant variation $(\mathrm{p}<0.05)$ was observed between the means of the blood groups in the females, no such variation was seen the males. Strong positive correlations were observed between the lipoproteins in blood group $\mathrm{B}, \mathrm{AB}$ and $\mathrm{O}$ females. As a result of the fact the rate of prevalence of CVD in our population is increasing, it is recommended that diagnosis, management and treatment of CVD in Nigeria should take into consideration the blood group status of the subjects. (C) JASEM

https://dx.doi.org/10.4314/jasem.v21i6.1
\end{abstract}

Key Words: Lipoproteins, Blood groups, cardiovascular diseases, triglycerides

After the discovery of ABO blood groups (Lansteiner, 1900), several studies have reported that the occurence of some diseases can be correlated with blood group types e.g. carcinoma of stomach (Aird et al., 1953), cardiometabolic diseases (Edgren et al., 2010), peptic ulcer (Risch et al., 2013), and upper urinary tract cancer (Gates et al., 2011). Several reports have also suggested an association of the ABO blood groups with the risk of developing severe manifestation of atherosclerosis (Meade et al., 1994). However, Saha, et al. (1973) and Nydegger et al. (2003) found that the $\mathrm{O}$ and $\mathrm{B}$ blood groups are predominant in patients with myocardial infarction and may play a role in the pathogenesis of myocardial infarction.

Stakishaitis et al. (2002) reported that the rate of prevalence of coronary atherosclerosis in Lithuanian women may be related to their B blood group type. Mitchell (1977) had earlier reported that higher rates of cardiovascular mortality in towns in Britain occurs among people with a higher prevalence of blood group "O". Mortality resulting from cardiovascular diseases was therefore suggested to be more in subjects with blood group "O" and the geographic variation in cardiovascular diseases was also attributed to the differences in the distribution of blood group "O" in different parts of Britain. Other studies also indicate that $\mathrm{ABO}$ blood group might influence plasma lipid levels (Wong et al., 1992). Lack of investigations examining the association between $\mathrm{ABO}$ blood groups and CVD in Nigeria especialy adult residents of River state extraction in the face of established prevalence of cardiovascular disease risk factors amongst citizens of the state was recognized as an important lacuna to be filled. Thus, this study was designed to investigate the relationship between $\mathrm{ABO}$ blood groups and lipoprotein profiles of adult reisidents in Rivers state.

\section{MATERIALS AND METHODS}

Subject Characteristics: The subjects were patients selected from those attending routine clinic at Braithwaite Memorial Specialist Hospital, Port Harcourt. Ethical clearance for the study was approved by the Local Ethics Committee of the Braithwaite Memorial Specialist Hospital and the subjects willingly consented to participate in the study after due explanation of the purpose of the study was done.

Collection of Blood Specimen: $5 \mathrm{ml}$ of blood samples were collected from patients, $1 \mathrm{ml}$ blood was immediately put into EDTA bottle and the remaining $4 \mathrm{ml}$ of blood was put in a plain bottle and both were labeled, capped and the EDTA sample was gently mixed with the anticoagulant and used for the blood groups determination while samples in the plain bottles were allowed to clot before centrifuging for five minutes at 6000 revolutions/minute and the serum were separated immediately into plain sterile sample bottles with Pasteur pipette and frozen in the refrigerator at $-4^{\mathrm{O}}{ }_{\mathrm{C}}$ for (1-14) days. Lipid profile analyses were done within this period.

Biochemical determinations: Determination of serum total cholesterol: 
The enzymatic procedure for total cholesterol determination in serum based upon the Trinder (1969) method as modified by the Centers for Disease Control and Prevention was used. The method is popularly known as the enzymatic endpoint method. Cholesterol esterases (CHE) hydrolyze the cholesterol esters into free cholesterol. Cholesterol oxidase (CHOD) oxidizes the cholesterol into cholest-4-en-3-one and hydrogen peroxide. Hydrogen peroxide reacts with a mixture of 4-aminoantipyrene and phenol in the presence of peroxidase enzyme (POD) and converts the reactants into a red quinone dye. The absorbance of the quinoneimine is directly proportional to the cholesterol concentration when measured at $520 \mathrm{~nm}$.

Determination of serum high density lipoprotein cholesterol : The method of Lopes-Virella et al. (1977) for the determination of high-density cholesterol in serum was employed. Low density lipoproteins and very low density lipoproteins (LDL and VLDL) and chylomicron fractions are precipitated quantitatively by the addition of phosphotungstic acid in the presence of magnesium ions. After centrifugation, the cholesterol concentration in the HDL (high density lipoprotein) fraction, which remains in the supernatant, is determined at $520 \mathrm{~nm}$.

Determination of serum low density lipoprotein cholesterol: The Friedewald et al. (1972) equation was used to calculate the LDL-cholesterol in $\mathrm{mmol} / \mathrm{L}$. LDL-cholesterol in plasma was calculated, using the result obtained from estimation of total cholesterol.
Enzymatic Determination of serum triglycerides: The colorimetric method of Tietz (1995) was employed. Lipase hydrolyses triglycerides sequentially to di \& monoglycerides and finally to glycerol. Glycerol kinase (GK) using ATP as phosphate source converts glycerol liberated to glycerol-3-phosphate (G-3Phosphate). Glycerol-3-phosphate oxidase (GPO) oxidizes Glycerol-3-phosphate and forms dihydroxy acetone phosphate and hydrogen peroxide. Peroxidase (POD) uses the hydrogen peroxide formed, to oxidize 4-aminoantipyrine and TOOS (Nethyl-N-sulphohydroxy propyl-m-toluidine) to a purple coloured complex. The absorbance of the coloured complex is measured at $520 \mathrm{~nm}$ and is proportional to triglyceride concentration in the sample

ABO blood grouping: $\mathrm{ABO}$ and $\mathrm{Rh}$ blood groupings were carried out by standard tile techniques (Lewis et al., 2001) with appropriate positive and negative controls using one drop of whole blood mixed with one drop of appropriate antisera and rocked gently for agglutination. Quality monoclonal blood grouping reagents manufactured by Rapid Labs Limited, United Kingdom were used.

Statistical analysis: The results were statistically analyzed using the Statistical Package for Social Sciences (SPSS) version 21. Data values are given as mean, standard deviation, percentages and correlation coefficients. Comparison between test carried out in the different blood groups according to the male and female populations respectively were made using single factor analysis (ANOVA) and results were considered significant at $\mathrm{p}<0.05$.

\section{RESULTS AND DISCUSSION}

Results were obtained from 150 subjects for determination of biochemical risk factors of cardiovascular diseases, among the various blood group of both female and male populations. The age range for the male subjects was 17-88 years while that for the female population was 25-76 years. The demographic distribution of the blood groups in the subjects is shown in table 1 .

Table 1: Demographic Distribution of the Blood Group Antigens in the Population

\begin{tabular}{cccccc}
\hline Sex & $\begin{array}{c}\text { Blood } \\
\text { group A }\end{array}$ & $\begin{array}{c}\text { Blood } \\
\text { group B }\end{array}$ & $\begin{array}{c}\text { Blood } \\
\text { group AB }\end{array}$ & $\begin{array}{c}\text { Blood } \\
\text { group O }\end{array}$ & Total \\
\hline Male & $12(8 \%)$ & $10(6.67 \%)$ & $3(2 \%)$ & $36(24 \%)$ & $61(40.67 \%)$ \\
Female & $24(16 \%)$ & $14(9.33 \%)$ & $3(2 \%)$ & $48(32 \%)$ & $89(53.33 \%)$ \\
Total & $36(24 \%)$ & $24(16 \%)$ & $6(4 \%)$ & $84(56 \%)$ & $150(100 \%)$ \\
\hline
\end{tabular}

The analysis of mean \pm SD concentration of total cholesterol (TC), low density lipoprotein (LDL), high density lipoprotein (HDL), triglycerides and very low density lipoprotein (VLDL in the male subjects by blood groups is shown in table 2 . The table shows that the mean $\pm \mathrm{SD}$ of total cholesterol was $5.01 \pm 1.63 \mathrm{mmol} / \mathrm{L}$ in blood group $\mathrm{A}, 5.70 \pm 1.00 \mathrm{mmol} / \mathrm{L}$ in blood group $\mathrm{B}, 4.86 \pm 1.52 \mathrm{mmol} / \mathrm{L}$ in group $\mathrm{O}$ and $5.48 \pm 1.62 \mathrm{mmol} / \mathrm{l}$ in blood group $\mathrm{AB}$ subjects. The mean $\pm \mathrm{SD}$ of triglycerides of blood group A, blood group $\mathrm{B}, \mathrm{AB}$ and blood group $\mathrm{O}$ subjects were $1.08 \pm$ $0.74 \mathrm{mmol} / \mathrm{L}, 1.28 \pm 0.64 \mathrm{mmol} / \mathrm{L}$, $0.99 \pm 0.36 \mathrm{mmol} / \mathrm{L}$ and $1.25 \pm 0.40$ $\mathrm{mmol} / \mathrm{L}$ respectively. The table also shows that blood group A male subjects had mean \pm SD of HDL-C of $0.69 \pm 0.25 \mathrm{mmol} / 1$, blood group $B$ had $0.67 \pm 0.17 \mathrm{mmol} / \mathrm{L}$, blood group $\mathrm{O}$ had $0.69 \pm 0.28 \mathrm{mmol} / \mathrm{L}$ and $0.79 \pm 0.22 \mathrm{mmol} / \mathrm{L}$ for blood group $\mathrm{AB}$. The mean $\pm \mathrm{SD}$ of $\mathrm{LDL}$ in blood group A, group B, group O and group $\mathrm{AB}$ subjects were 3.84 $\pm 1.73 \mathrm{mmol} / \mathrm{L}, 3.85 \pm 0.88 \mathrm{mmol} / \mathrm{L}$, $3.61 \pm 1.41 \mathrm{mmol} / \mathrm{L}$ and $4.24 \pm 1.37$ $\mathrm{mmol} / \mathrm{L}$ respectively. The mean \pm SD of VLDL in blood group $\mathrm{A}$ subjects was $0.49 \pm 0.34 \mathrm{mmol} / \mathrm{L}$; in blood group B subjects it was 0.58 $\pm 0.29 \mathrm{mmol} / \mathrm{L}, 0.57 \pm 0.18 \mathrm{mmol} / \mathrm{L}$ for blood group $\mathrm{O}$ subjects while 
$0.45 \pm 0.16 \mathrm{mmol} / \mathrm{L}$ is the VLDL value in group $\mathrm{AB}$ subjects. . Comparison of the means of the lipoproteins among the blood groups did not show significant difference $(\mathrm{p}>0.05)$

Table 2: Mean \pm SD of TC, TG, LDL, HDL and VLDL, in male subjects by blood groups

\begin{tabular}{llllll}
\hline $\begin{array}{l}\text { Blood } \\
\text { Groups }\end{array}$ & $\begin{array}{c}\mathrm{TG}^{\mathrm{d}} \\
(\mathrm{mmol} / \mathrm{L})\end{array}$ & $\begin{array}{c}\mathrm{TC}^{\mathrm{a}} \\
(\mathrm{mmol} / \mathrm{L})\end{array}$ & $\begin{array}{c}\mathrm{HDL}^{\mathrm{b}} \\
(\mathrm{mmol} / \mathrm{L})\end{array}$ & $\begin{array}{c}\mathrm{LDL}^{\mathrm{c}} \\
(\mathrm{mmol} / \mathrm{L})\end{array}$ & $\begin{array}{c}\mathrm{VLDL} \\
(\mathrm{mmol} / \mathrm{L})\end{array}$ \\
\hline & & & & & \\
Group A & $1.08 \pm 0.74$ & $5.01 \pm 1.63$ & $0.69 \pm 0.25$ & $3.84 \pm 1.73$ & $0.49 \pm 0.34$ \\
Group B & $1.28 \pm 0.64$ & $5.70 \pm 1.00$ & $0.67 \pm 0.17$ & $3.85 \pm 0.88$ & $0.58 \pm 0.29$ \\
Group O & $1.25 \pm 0.40$ & $4.86 \pm 1.52$ & $0.69 \pm 0.28$ & $3.61 \pm 1.41$ & $0.57 \pm 0.18$ \\
Group & & & & & \\
AB & $0.99 \pm 0.36$ & $5.48 \pm 1.62$ & $0.79 \pm 0.22$ & $4.24 \pm 1.37$ & $0.45 \pm 0.16$ \\
F-value & 0.7107 & 0.3368 & 0.5426 & 0.4024 & 0.7107 \\
p-value & 0.550 & 0.868 & 0.921 & 0.751 & 0.552 \\
\hline
\end{tabular}

Table 2a: ANOVA table of comparison of means of TG amongst the blood groups in males

\begin{tabular}{|c|c|c|c|}
\hline & SS & $\mathrm{df}$ & MS \\
\hline Treatment (between columns) & 0.5624 & 3 & 0.1872 \\
\hline Residual (within coluns) & 15.83 & 60 & 0.2638 \\
\hline Total & 16.39 & 63 & \\
\hline
\end{tabular}

Table 2b: ANOVA table of comparison of means of total cholest. amongst the blood groups in males

\begin{tabular}{lccc}
\hline & SS & df & MS \\
\hline Treatment (between columns) & 2.216 & 3 & 0.7388 \\
Residual (within coluns) & 131.6 & 60 & 2.194 \\
Total & 133.8 & 63 & \\
\hline
\end{tabular}

Table 2c: ANOVA table of comparison of means of HDL-C among the blood groups in males

\begin{tabular}{lccl}
\hline & SS & df & MS \\
\hline Treatment (between columns) & 0.1031 & 3 & 0.03438 \\
Residual (within coluns) & 3.802 & 60 & 0.06337 \\
Total & 3.905 & 63 & \\
\hline
\end{tabular}

Table 2d: ANOVA table of comparison of means LDL-C among the blood groups in males

\begin{tabular}{lccc}
\hline & SS & df & MS \\
\hline Treatment (between columns) & 2.398 & 3 & 0.7992 \\
Residual (within coluns) & 119.2 & 60 & 1.986 \\
Total & 121.6 & 63 & \\
\hline
\end{tabular}

Table 2e: ANOVA table of comparison of means of VLDL-C among the blood groups in males

\begin{tabular}{lccc}
\hline & SS & df & MS \\
\hline Treatment (between columns) & 0.16662 & 3 & 0.038774 \\
Residual (within coluns) & 3.270 & 60 & 0.05451 \\
Total & 3.387 & 63 & \\
\hline
\end{tabular}

The analysis of mean \pm SD of total cholesterol (TC), triglycerides (TG), high density lipoprotein (HDL), low density lipoprotein (LDL) and very low density lipoprotein (VLDL) of the female subjects by their blood groups is shown in Table 3. The analysis of the mean $\pm \mathrm{SD}$ of TC was $6.25 \pm 1.69 \mathrm{mmol} / \mathrm{L}$ for blood group A, $5.40 \pm 1.15 \mathrm{mmol} / \mathrm{L}$ for blood group B, $5.20 \pm 1.11 \mathrm{mmol} / \mathrm{L}$ for blood group $\mathrm{O}$ and $5.48 \pm 1.62$ $\mathrm{mmol} / \mathrm{L}$ for group $\mathrm{AB}$. The mean $\pm \mathrm{SD}$ of triglyceride is $1.15 \pm 0.46$ $\mathrm{mmol} / \mathrm{L}$ for blood group $\mathrm{A}, 1.49 \pm 0.61 \mathrm{mmol} / \mathrm{L}$ for group $\mathrm{B}, 1.16 \pm$ $0.47 \mathrm{mmol} / \mathrm{L}$ for group $\mathrm{O}$ and $0.99 \pm 0.36 \mathrm{mmol} / \mathrm{L}$ for blood group $\mathrm{AB}$.
The mean concentration of HDL was $0.72 \mathrm{mmol} / 1$ for blood group A, $0.73 \mathrm{mmol} / 1$ for blood group $\mathrm{B}$, $0.74 \mathrm{mmol} / 1$ for group $\mathrm{O}$ and $0.79 \mathrm{mmol} / \mathrm{l}$ for blood group $\mathrm{AB}$. The mean concentration of LDL for blood group A and group B was $4.81 \mathrm{mmol} / 1$ and $4.00 \mathrm{mmol} / 1$ while for blood group $\mathrm{O}$ and blood group $\mathrm{AB}$, it was $3.90 \mathrm{mmol} / \mathrm{l}$ and $4.24 \mathrm{mmol} / 1$ respectively. The mean concentration of VLDL for blood group $\mathrm{A}$, group $\mathrm{B}$, group $\mathrm{O}$ and group $\mathrm{AB}$ were $0.69 \mathrm{mmol} / 1$, $0.68 \mathrm{mmol} / 1, \quad 0.53 \mathrm{mmol} / 1$ and $0.45 \mathrm{mmol} / 1 \quad$ respectively. Significant variation $(\mathrm{p}<0.05)$ was observed between the means of triglycerides, total cholesterol, low density cholesterol and very low density lipoprotein cholesterol in the blood groups while no significant difference ( $p>0.05)$ was noticed in the mean of high density cholesterol between the blood groups. Turkey's multiple comparison test of the means of lipoproteins showed significant variation between triglycerides of blood group $\mathrm{O}$ and triglycerides of blood group A ( $q=4.097)$, total cholesterol of blood group A and total cholesterol of blood group total cholestrol of blood group $\mathrm{O}$ $(\mathrm{q}=4.390)$ and low density lipoproteins of blood group A and low density lipoprotein of blood group $\mathrm{O}(\mathrm{q}=4.350)$. The correlation of the lipoproteins of the blood groups shows that VLDL-C is strongly correlated positively with triglycerides for blood groups B, $\mathrm{AB}$ and $\mathrm{O}(\mathrm{r}=1.00)$ except in blood A where no correlation was observed. Positive correlations were also observed between triglycerides and total cholesterol in males $(\mathrm{r}=0.55)$ and females $(\mathrm{r}=0.56)$ with blood group $\mathrm{B}$ and blood group AB ( $\mathrm{r}=0.84)$. Total cholesterol and low density lipoprotein cholesterol correlated positively in males with blood group B $(\mathrm{r}=0.91)$, females with blood group B $(\mathrm{r}=0.56)$, female with blood group $\mathrm{O}(\mathrm{r}=0.87)$ and subjects with blood group $\mathrm{AB}$ $(r=0.99)$. Results further shows strong positive correlations between total cholesterol and high 
density lipoprotein in females with blood group $\mathrm{O}(\mathrm{r}=0.50)$, and subjects of blood group $\mathrm{AB}$ ( $\mathrm{r}=0.62$ ) (table 4 and 5). Significantly, most of the lipoproteins were positively strongly correlated in the the subjects with $\mathrm{AB}$ blood group (table 4).

Table 3: Mean \pm SD of TC, TG, LDL, HDL and VLDL, in female subjects by blood groups

\begin{tabular}{llllll}
\hline $\begin{array}{c}\text { Blood } \\
\text { Groups }\end{array}$ & $\begin{array}{c}\text { TG } \\
(\mathrm{mmol} / \mathrm{L})\end{array}$ & $\begin{array}{c}\mathrm{TC} \\
(\mathrm{mmol} / \mathrm{L})\end{array}$ & $\begin{array}{c}\text { HDL } \\
(\mathrm{mmol} / \mathrm{L})\end{array}$ & $\begin{array}{c}\mathrm{LDL} \\
(\mathrm{mmol} / \mathrm{L})\end{array}$ & $\begin{array}{c}\text { VLDL } \\
(\mathrm{mmol} / \mathrm{L})\end{array}$ \\
\hline Group A & $1.51 \pm 0.48$ & $6.25 \pm 1.69$ & $0.72 \pm 0.22$ & $4.81 \pm 1.64$ & $0.69 \pm 0.22$ \\
Group B & $1.49 \pm 0.61$ & $5.40 \pm 1.15$ & $0.73 \pm 0.24$ & $4.00 \pm 1.04$ & $0.68 \pm 0.28$ \\
Group O & $1.16 \pm 0.47$ & $5.20 \pm 1.11$ & $0.74 \pm 0.21$ & $3.90 \pm 0.88$ & $0.53 \pm 0.21$ \\
Group AB & $0.99 \pm 0.36$ & $5.48 \pm 1.62$ & $0.79 \pm 0.22$ & $4.24 \pm 1.37$ & $0.45 \pm 0.16$ \\
F-value & 4.334 & 3.259 & 0.2970 & 3.280 & 4.334 \\
p-value & 0.007 & 0.025 & 0.948 & 0.025 & 0.0067 \\
\hline
\end{tabular}

Table 3a: ANOVA table of comparison of means triglycerides among the blood groups

\begin{tabular}{|c|c|c|c|}
\hline & SS & df & MS \\
\hline Treatment (between columns) & 3.168 & 3 & 1.056 \\
\hline Residual (within coluns) & 21.44 & 88 & 0.2437 \\
\hline Total & 24.61 & 91 & \\
\hline
\end{tabular}

Table 3b: ANOVA table of comparison of means triglycerides among the blood groups in males

\begin{tabular}{cccc}
\hline & SS & df & MS \\
\hline Treatment (between columns) & 17.37 & 3 & 5.790 \\
Residual (within coluns) & 156.3 & 88 & 1.776 \\
& & & \\
Total & 173.7 & 91 & \\
\hline
\end{tabular}

Table 3c: ANOVA table of comparison of means HDL-C among the blood groups in males

\begin{tabular}{cccc}
\hline & SS & df & MS \\
\hline Treatment (between columns) & 0.04417 & 3 & 0.01472 \\
Residual (within coluns) & 4.362 & 88 & 0.04957 \\
Total & 4.407 & 91 & \\
\hline
\end{tabular}

Table 3d: ANOVA table of comparison of means LDL-C among the blood groups in males

\begin{tabular}{cccc}
\hline & SS & df & MS \\
\hline Treatment (between columns) & 13.87 & 3 & 4.623 \\
Residual (within coluns) & 124.0 & 88 & 1.409 \\
Total & 137.9 & 91 & \\
\hline
\end{tabular}

Table 3e: ANOVA table of comparison of means VLDL-C among the blood groups in males

\begin{tabular}{cccc}
\hline & SS & df & MS \\
\hline Treatment (between columns) & 0.6546 & 3 & 0.2182 \\
Residual (within coluns) & 4.431 & 88 & 0.05035 \\
Total & 5.085 & 91 & \\
\hline
\end{tabular}

Table 4: Correlation coefficients of lipoproteins among the AB blood group

\begin{tabular}{lc}
\multicolumn{1}{c}{ Lipoproteins } & *AB Blood group $(\mathrm{r})$ \\
\hline TG vs TC & 0.84 \\
TG vs HDL & 0.64 \\
TG vs LDL & 0.77 \\
TG vs VLDL & 1.00 \\
TC vs HDL & 0.62 \\
TC vs LDL & 0.99 \\
TC vs VLDL & 0.85 \\
HDL vs LDL & 0.50 \\
HDL vs VLDL & 0.67 \\
LDL vs VLDL & 0.78 \\
\hline
\end{tabular}

*The subjects in this blood group were combined.

The computation of the cardiovascular disease risk profile of the subjects based on the recommendations of the National Cholesterol Education Program, Adult Treatment Panel 111 of 2003 according to the blood groups using total cholesterol as the risk factor shows that risk in the males was highest in blood group A $(33.33 \%)$ followed by blood group B (16.67\%) while females of blood group $\mathrm{AB}$ exhibited highest risk profile $(66.67 \%)$ followed by blood group A $(54.17 \%)$ (table 6). When high density lipoprotein (HDL-C) was used to determine the CVD risk profile of the subjects by blood groups, the result revealed that the concentration of HDL-C in the subjects in all the blood groups was generally low resulting in very high risk profile in the range of $89.89 \%$ to $100 \%$ in both the males and female subjects for all blood groups (table 7)

The percentage categorization of the CVD risk profile of the blood groups in the male subjects using low density lipoprotein cholesterol (LDL-C) shows that the risk of CVD was highest in subjects of blood group A (41.67\%), followed by blood group AB (33.33\%), blood group $\mathrm{O}(30.56 \%)$ and blood group B $(20.00 \%)$. In the females, the risk profile for CVD increased in the order of blood group $\mathrm{AB}$ $(67.67 \%)$, blood group A $(62.50 \%)$, blood group O $(41.67 \%)$ and blood group B (35.71\%) (table 8$)$. The cardiovascular disease risk profile of the subjects in the all blood groups using triglycerides as the risk factor were within the desirable limits $(<2.83 \mathrm{mmol} / \mathrm{L})$ except for $2.08 \%$ of blood group $\mathrm{O}$ females that showed moderate risk profile (table 9). The percentage risk level of the male and female subjects in the various blood group groups according to the cardiovascular risk risk factors (total cholesterol, high density lipoprotein cholesterol and low density lipoprotein cholesterol) is shown in figures 1 to 6 . 
Table 5: Correlation coefficients of lipoproteins among the blood groups in male and female subjects

\begin{tabular}{|c|c|c|c|c|c|c|}
\hline \multirow[t]{2}{*}{ Lipoproteins } & \multicolumn{3}{|c|}{ Males } & \multicolumn{3}{|c|}{ Females } \\
\hline & $\begin{array}{c}\text { Blood } \\
\text { group A } \\
\text { (r) }\end{array}$ & $\begin{array}{l}\text { Blood } \\
\text { group B } \\
(\mathrm{r})\end{array}$ & $\begin{array}{c}\text { Blood } \\
\text { group O } \\
(\mathrm{r})\end{array}$ & $\begin{array}{c}\text { Blood } \\
\text { group A } \\
(\mathrm{r})\end{array}$ & $\begin{array}{c}\text { Blood } \\
\text { group B } \\
\text { (r) }\end{array}$ & $\begin{array}{c}\text { Blood } \\
\text { group } \mathrm{O} \\
(\mathrm{r})\end{array}$ \\
\hline TG vs LDL & 0.98 & - & - & - & - & - \\
\hline TG vs TC & - & 0.55 & - & - & 0.56 & - \\
\hline TG vs VLDL & - & 1.00 & 1.00 & - & 1.00 & 1.00 \\
\hline TC vs LDL & - & 0.91 & - & - & 0.56 & 0.87 \\
\hline TC vs VLDL & - & 0.55 & - & - & - & - \\
\hline TC vs HDL & - & - & - & - & - & 0.50 \\
\hline
\end{tabular}

Table 6: Percentage categorization of CVD risk profile of the blood groups using total cholesterol level

\begin{tabular}{ccccccccc}
\hline $\begin{array}{c}\text { Risk level } \\
(\mathrm{mmol} / \mathrm{L})\end{array}$ & \multicolumn{2}{c}{ Blood group A } & \multicolumn{2}{c}{ Blood group B } & \multicolumn{2}{c}{ Blood group AB } & \multicolumn{2}{c}{ Blood group O } \\
\cline { 2 - 8 } & Male & Females & Males & Females & Males & Females & Males & Females \\
Desirable & $58.32 \%$ & $29.17 \%$ & $50.00 \%$ & $57.14 \%$ & $66.67 \%$ & $0.00 \%$ & $63.89 \%$ & $54.17 \%$ \\
$(<5.81)$ & $(3.81)$ & $(4.20)$ & $(4.25)$ & $(4.64)$ & $(3.80)$ & & $(3.94)$ & $(4.48)$ \\
Moderate & $8.33 \%$ & $16.67 \%$ & $40.00 \%$ & $21.43 \%$ & $33.33 \%$ & $33.33 \%$ & $19.44 \%$ & $33.33 \%$ \\
$(5.81-6.18)$ & $(5.32)$ & $(5.85)$ & $(5.75)$ & $(5.68)$ & $(5.63)$ & $(5.02)$ & $(5.70)$ & $(5.65)$ \\
High & $33.33 \%$ & $54.17 \%$ & $10.00 \%$ & $21.43 \%$ & $0.00 \%$ & $66.67 \%$ & $16.67 \%$ & $12.50 \%$ \\
$(\geq 6.22)$ & $(7.02)$ & $(7.45)$ & $(6.99)$ & $(7.17)$ & & $(7.33)$ & $(7.40)$ & $(7.15)$ \\
\hline
\end{tabular}

Table 7: Percentage categorization of CVD risk profile of the blood groups using high density lipoprotein level

\begin{tabular}{|c|c|c|c|c|c|c|c|c|}
\hline \multirow{2}{*}{$\begin{array}{c}\text { Risk } \\
\text { level } \\
(\mathrm{mmol} / \mathrm{L})\end{array}$} & \multicolumn{2}{|c|}{ Blood group A } & \multicolumn{2}{|c|}{ Blood group B } & \multicolumn{2}{|c|}{ Blood group $\mathrm{AB}$} & \multicolumn{2}{|c|}{ Blood group O } \\
\hline & Male & Females & Males & Females & Males & Females & Males & Females \\
\hline $\begin{array}{c}\text { Desirable } \\
(\geq 1.55)\end{array}$ & $0.00 \%$ & $\begin{array}{l}4.17 \% \\
(1.55)\end{array}$ & $0.00 \%$ & $0.00 \%$ & $0.00 \%$ & $0.00 \%$ & $\begin{array}{l}2.78 \% \\
(1.74)\end{array}$ & $0.00 \%$ \\
\hline $\begin{array}{c}\text { Moderate } \\
(1.02- \\
1.50)\end{array}$ & $\begin{array}{l}8.33 \% \\
(1.33)\end{array}$ & $0.00 \%$ & $0.00 \%$ & $\begin{array}{l}7.14 \% \\
(1.22)\end{array}$ & $0.00 \%$ & $0.00 \%$ & $\begin{array}{l}8.33 \% \\
(1.16)\end{array}$ & $\begin{array}{l}8.33 \% \\
(1.28)\end{array}$ \\
\hline $\begin{array}{c}\text { High } \\
(<1.02)\end{array}$ & $\begin{array}{c}91.67 \% \\
(0.64)\end{array}$ & $\begin{array}{c}95.83 \% \\
(0.69)\end{array}$ & $\begin{array}{c}100.00 \% \\
(0.67)\end{array}$ & $\begin{array}{c}92.86 \% \\
(0.69)\end{array}$ & $\begin{array}{c}100.00 \% \\
(0.64)\end{array}$ & $\begin{array}{c}100.00 \% \\
(0.93)\end{array}$ & $\begin{array}{c}88.89 \% \\
(0.61)\end{array}$ & $\begin{array}{c}91.67 \% \\
(0.69)\end{array}$ \\
\hline
\end{tabular}

Table 8: Percentage categorization of CVD risk profile of the blood groups using low density cholesterol level

\begin{tabular}{ccccccccc}
\hline \multirow{2}{*}{$\begin{array}{c}\text { Risk level } \\
(\mathrm{mmol} / \mathrm{L})\end{array}$} & \multicolumn{2}{c}{ Blood group A } & \multicolumn{2}{c}{ Blood group B } & \multicolumn{2}{c}{ Blood group AB } & \multicolumn{2}{c}{ Blood group O } \\
\cline { 2 - 8 } & Male & Females & Males & Females & Males & Females & Males & Females \\
\hline Desirable & $58.33 \%$ & $20.83 \%$ & $40.00 \%$ & $21.43 \%$ & $66.67 \%$ & $0.00 \%$ & $55.56 \%$ & $20.83 \%$ \\
$(<3.37)$ & $(2.55)$ & $(2.65)$ & $(2.91)$ & $(2.78)$ & $(2.96)$ & & $(2.68)$ & $(2.64)$ \\
Moderate & $0.00 \%$ & $16.67 \%$ & $20.00 \%$ & $42.86 \%$ & $0.00 \%$ & $33.33 \%$ & $13.88 \%$ & $37.50 \%$ \\
$(3.37-$ & & $(3.53)$ & $(4.04)$ & $(3.74)$ & & $(3.75)$ & $(3.63)$ & $(3.73)$ \\
$4.12)$ & & & & & & & & \\
High & $41.67 \%$ & $62.50 \%$ & $40.00 \%$ & $35.71 \%$ & $33.33 \%$ & $66.67 \%$ & $30.56 \%$ & $41.67 \%$ \\
$(\geq 4.14)$ & $(5.65)$ & $(5.88)$ & $(4.71)$ & $(5.03)$ & $(4.25)$ & $(5.86)$ & $(5.28)$ & $(4.68)$ \\
\hline
\end{tabular}

Table 9: Percentage categorization of CVD risk profile of the blood groups using triglycerides level

\begin{tabular}{|c|c|c|c|c|c|c|c|c|}
\hline \multirow{2}{*}{$\begin{array}{l}\text { Risk level } \\
(\mathrm{mmol} / \mathrm{L})\end{array}$} & \multicolumn{2}{|c|}{ Blood group A } & \multicolumn{2}{|c|}{ Blood group B } & \multicolumn{2}{|c|}{ Blood group $\mathrm{AB}$} & \multicolumn{2}{|c|}{ Blood group $\mathrm{O}$} \\
\hline & Male & Females & Males & Females & Males & Females & Males & Females \\
\hline $\begin{array}{c}\text { Desirable } \\
(<2.83)\end{array}$ & $\begin{array}{c}100.00 \% \\
(1.08)\end{array}$ & $\begin{array}{l}100 \% \\
(1.51)\end{array}$ & $\begin{array}{c}100.00 \% \\
(1.28)\end{array}$ & $\begin{array}{l}100.00 \% \\
(1.49)\end{array}$ & $\begin{array}{c}100.00 \% \\
(0.83)\end{array}$ & $\begin{array}{c}100.00 \% \\
(1.16)\end{array}$ & $\begin{array}{c}100.00 \% \\
(1.25)\end{array}$ & $\begin{array}{c}97.92 \% \\
(1.11)\end{array}$ \\
\hline $\begin{array}{c}\text { Moderate } \\
(2.83- \\
5.65)\end{array}$ & $0.00 \%$ & $0.00 \%$ & $0.00 \%$ & $0.00 \%$ & $0.00 \%$ & $0.00 \%$ & $0.00 \%$ & $\begin{array}{l}2.08 \% \\
(3.38)\end{array}$ \\
\hline $\begin{array}{c}\text { High } \\
(>5.65)\end{array}$ & $0.00 \%$ & $0.00 \%$ & $0.00 \%$ & $0.00 \%$ & $0.00 \%$ & $0.00 \%$ & $0.00 \%$ & $0.00 \%$ \\
\hline
\end{tabular}

Note: The categorization of the risk levels was done based on the criteria of the National Cholesterol Education Programme, Adult Treatment Panel III, 2003. Number in parenthesis represents mean of parameters.

Discussion: In the last few decades, concertive efforts have been put into studies aimed at establishing a link between the ABO blood groups and the incidence of cardiovascular diseases (Ketch et al., 2008; Kaur 2012). it has been severally reported that the relationship between $\mathrm{ABO}$ blood groups and the development of cardiovascular disease as reported in 
various literatures is still very unclear (Alireza et al., 2006; Bianca et al., 2002). Hypercholesterolaemia is usually considered a cardiovascular risk which could predispose to the development of ischaemic heart disease (Grover et al., 1995). Apart from high levels of total cholesterol, low levels of high density lipoprotein cholesterol, elevated low density lipoprotein cholesterol level and high levels of triglycerides are also important and recognized risk factors of cardiovascular diseases (Grover et al., 1995).

The results obtained from the analysis of the lipoprotein levels in this study shows that the mean of the total cholesterol and low density lipoprotein cholesterol of most of the subjects in all the blood groups appeared desirable $(<5.81 \mathrm{mmol} / \mathrm{L}$ and $<3.37$ $\mathrm{mmol} / \mathrm{L}$ ) respectively in both males and females. The triglycerides level in the subjects in the various blood groups was desirable $(<2.83 \mathrm{mmol} / \mathrm{L})$. When the total cholesterol was categorized into the various risk levels, the non $\mathrm{O}$ blood groups showed higher cardiovascular risk profile. Females of blood $\mathrm{AB}$ showed highest risk profile $(66.67 \%)$ with total cholesterol, $100 \%$ risk profile with HDL-C and $66.67 \%$ with low density lipoprotein cholesterol. The triglycerides level in the population was within the desirable limit $(<2.83 \mathrm{mmol} / \mathrm{L})$. The males with $\mathrm{AB}$ blood group only showed moderate risk $(33.33 \%)$ with total cholesterol, high risk (100\%) with HDL-C and $33.33 \%$ with LDL-C. Anjum et al. (2017) reported that in a Saudi Arabian population, individuals of blood group $\mathrm{AB}$ showed highest cardiovascular risk with serum total cholesterol. This finding agrees with the observation made in this study particularly in the females. Also, in their findings, Meade et al. (1994) and Girgla et al. (2011) reported that ischaemic heart disease occurred more in subjects with blood group $\mathrm{AB}$ phenotype.

Similarly, we observed that females $(54.17 \%)$ and males $(33.33 \%)$ of blood group A respectively ranked second in the development of CVD risk with total cholesterol. The CVD risk profile using HDL-C for the blood group A subjects was $91.67 \%$ and $95.83 \%$ in the male and female respectively while the risk profile for the blood group A subjects with LDL-C was also highest in the females $(62.50 \%)$ than in the males $(41.67 \%)$. This finding is in agreement with results obtained from several studies. In a study among British men, the incidence of heart diseases was reported to be higher in patients with blood group A (Whincup et al. 1990). Similar finding was also reported among Hungarian general population (Tarjan et al., 1995). Whincup et al. (1990) and Akhand et al. (2001) also reported that excess coronary artery disease has been observed in blood group A individuals while a deficit of incidence occurred in blood $\mathrm{O}$ individuals irrespective of the sex. Positive coronary angiography was reported to be more frequent in blood group A individuals (Tarjan et al. 1995). Also, Skaik (2009) found that myocardial infarction was most common in blood group A $(57 \%)$ patients in Gaza Stripe of Palestine. These obsrvations are, however, in contrast and conflicting with results that reported higher risk in individuals with blood group $\mathrm{AB}$ as reported above.

The blood group category in our study that ranked third in the development of cardiovascular risk with total cholesterol was blood group B females $(21.43 \%)$ while $10.00 \%$ was noticed in the blood group B males. CVD risk was equally high with HDL-C as with other blood groups in the population studied. The CVD risk profile with LDL-C was, however, higher in males $(40.00 \%)$ than in the females $(35.71 \%)$. Nydegger et al. (2003) indicated that the ABO blood group B allele was an independent risk factor for myocardial infarction. In a study in Indian, Garg et al. (2012) further reported that there is a significant association between myocardial infarction and blood group B. Our observation did not reveal blood group B phenotype as the blood group most at risk of cardiovascular disease.

It is worthy to note that blood group $\mathrm{O}$ individuals in this study exhibited less cardiovascular risk profile with total cholesterol (16.67\%) and (12.50\%) and low density lipoprotein cholesterol $(30.56 \%)$ and $41.67 \%$ in both males and females when compared with the other blood groups respectively. This observation is, however, inconsistent with the observation of Anvari and his colleagues (2009), and Mitchell (1977) who reported that towns with a higher prevalence of blood group $\mathrm{O}$ had higher rates of cardiovascular mortality, whereas Meade et al. (1994) reported significantly higher incidence of ischaemic heart disease in blood group $\mathrm{AB}$ as compared to those of $\mathrm{B}$ and $\mathrm{A}$. Another contrast to the above observations was a systematic review and meta-analysis which documented that having a non-O blood group carries an approximately two-fold increased risk of venous thrombosis (Dentali et al., 2012).

Another striking observation made in this study was the discovery that though the triglycerides level in the various blood groups were within the desisable limits $(<2.83 \mathrm{mmol} / \mathrm{L})$, strong positive correlations were observed between the triglycerides level and other atherogenic lipoproteins in the male blood group B, female blood blood group B, and female blood group $\mathrm{O}$ subjects. This could account for the higher prevalence of cardiovascular risk in the females than the males in the population studied irrespective of the blood groups.

In this study, gender distribution of CVD risk was profoundly observed. It is possible that genetic variation and make up of the Nigerian population which differed profoundly from the western and 
Asian populations where some of these studies were performed could have accounted for this disparity in sex ditribution of risk profile in the blood groups. However, some authors reported that gender distribution have no significant association with blood groups in ischaemic heart disease in patients (Abdollahi et al. 2009; Lutfullah et al. 2010).

Despite the findings in this study, it is important to state that the results from some cohort studies show that the prevalence of cardiovascular disease in various blood groups was almost similar to that in controls and no significant association was found between $\mathrm{ABO}$ blood groups and cardiovascular disease.Sari et al. (2008) reported that the distribution of $\mathrm{ABO}$ blood groups in patients with myocardial infarction was quite similar to that in control group and that of general Turkish population, which supports the idea that $\mathrm{ABO}$ blood group might not be significantly associated with the development of cardiovascular disease.

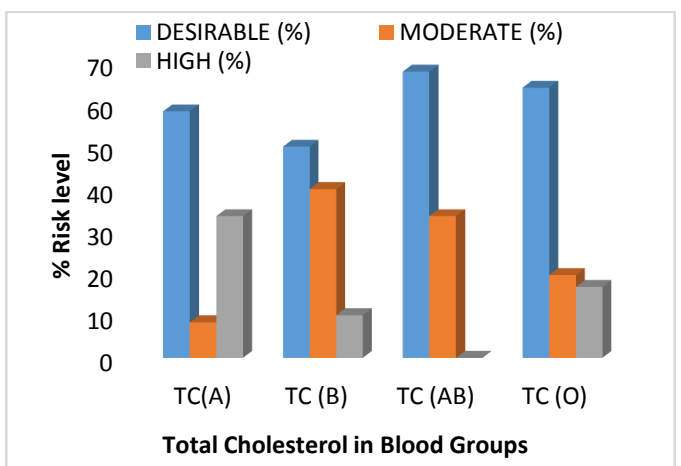

Fig.1: Percentage Risk Level of Male Subjects with TC amongst the Blood Groups

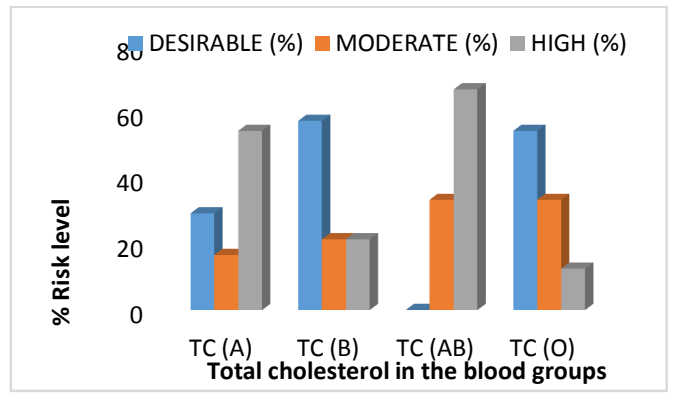

Fig.2: Percentage Risk Level of Female Subjects with TC amongst the Blood Groups

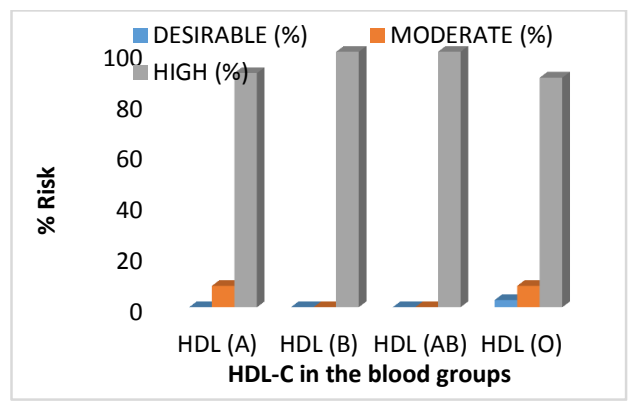

Fig. 3: Percentage Risk Level of Male Subjects with HDL-C amongst the Blood Groups

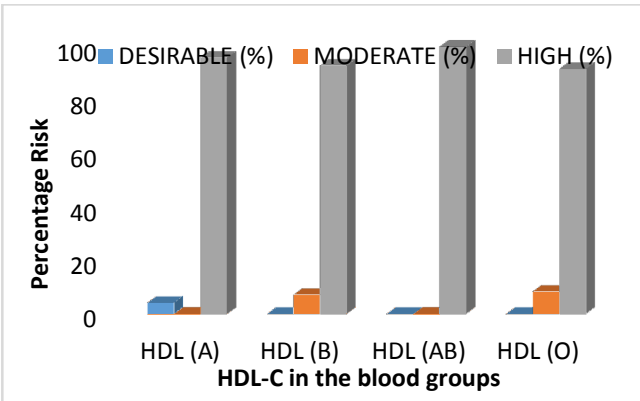

Fig. 4: Percentage Risk Level of Female Subjects with HDL-C Amongst Blood Groups

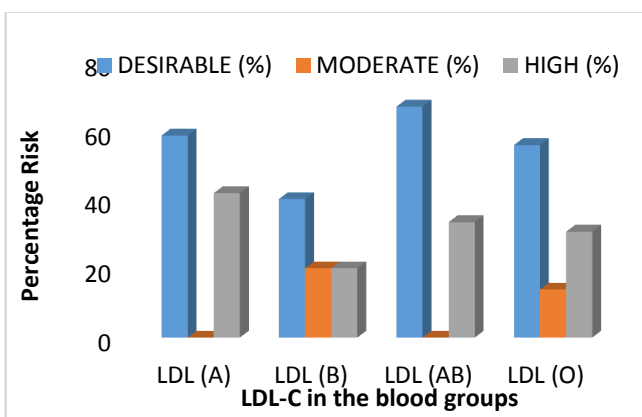

Fig. 5: Percentage Risk Level of Male Subjects with LDL-C amongst the Blood Groups

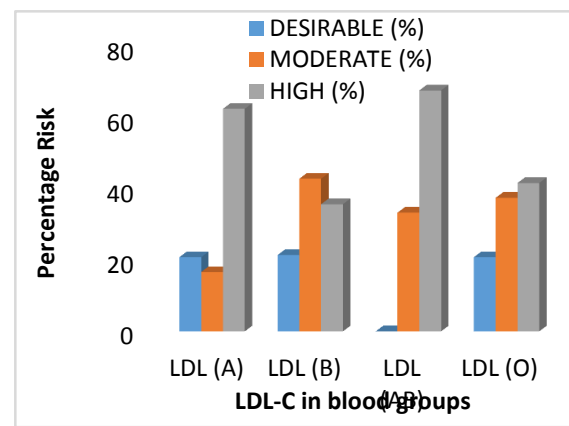

Fig. 6: Percentage Risk Level of Female Subjects with LDL-C amongst the Blood Groups

In conclusion, looking at the contradictory results from cross-sectional studies of various racial groups, it is obvious that the relationship between $\mathrm{ABO}$ blood groups and CVDs is still not clear signifying need for more research to draw a decisive conclusion. However, it is reiterated that this study reveals that the prevalence of CVD risk is highest in blood group $\mathrm{AB}$, followed by blood group $\mathrm{A}, \mathrm{B}$ and $\mathrm{O}$ respectively with the females exhibiting higher prevalence than the males in each blood group. The implication of this finding is that since lipid profile is a genetic component, family history may play an important role in the development and pathogenesis of cardiovascular disease risk factors. Similarly, because the prevalence of CVD is on the increase in worldwide and in Nigeria, it is our opinion that diagnosis, management and treatment of CVD in 
Nigeria should take into consideration the blood group status of the subjects. Furthermore, a more elaborate study across Rivers State, Nigeria should be conducted to confirm the findings made in this study against the back drop that variation in demographic characteristics may affect the association of lipoprotein parameters with different blood groups.

\section{REFERENCES}

Abdollahi, AA., Qorbani, M., Salehi, A., Mansourian M. (2009). ABO blood groups distribution and cardiovascular major risk factors in healthy population. Iranian J Public Health, 38 (3), 123126.

Aird, I., Bentall, HH., Roberts, JAF. (1953). A relationship between cancer of stomach and the ABO blood groups.Brit. Med. J., 1, 799-801.

Akhund IA., Alvi, IA., Ansari, A.K., Mughal, MA., Akhund, AA. (2001). A study of relationship of ABO blood groups with myocardial infarction and angina pectoris. J. Ayub. Med Coll. Abbottabad,: 13 : 25-26.

Alireza, A., Salarifar, M., Sadeghian, S., Davoodi, G., Darbanian, C., Goodarzynejad, H. (2006). Correlation between $\mathrm{ABO}$ blood groups, major risk factors and coronary artery disease. Int. $J$ Cardiol. 110:256-258.

Anjum, F., Zaini, R., Kufia, R. (2017). Relationship of blood groups with risk factors of cardiovascular diseases in Saudi Arabian

Friedewald, WT., Levy, R.I., Fredrickson, DS. (1972). Estimation of the concentration of low density lipoprotein cholesterol in plasma without

Garg, P., Kumar, J., Choudhary, R., Chawla, VK. (2012 June). Association between ABO Blood Groups and Myocardial Infarction in Jodhpur City of India. J Bangladesh Soc Physio 7(1): 1317.

Gates, MA., Wolpin, BM., Cramer, DW., Hankinson, SE., Tworoger, SS. (2011). ABO blood group and incidence of epithelial ovarian cancer, Int $J$ Cancer 128(2): 482-486.

Girgla, KK., Kaur, J., Kiran, BK. (2011). Study of Serum Cholesterol and Lipoproteins in Relation To ABO Blood Groups in North Indian Population, Indian Journal of Fund Appl Life Sci 1(4): 68-72.

Grover, SA., Coupal, L., Xiao, PH. (1995). Identifying adults at increased risk of coronary disease, Journal of Amer Med Assoc 274(10): 801-806. population, Asian J Res Biol Pharm Sci 5 (1): 1624.

Anvari, M.S., Boroumand, MA., Emami, B., Karimi, A., Soleymanzadeh, M., Abbasi, S. H. (2009). ABO Blood Group and Coronary Artery Diseases in Iranian Patients Awaiting Coronary Artery Bypass Graft Surgery. Labmedicine 40: 528-530.

Biancari, F., Satta, J., Pokela, R. and Juvonen, T. (Nov. 1, 2002). ABO blood group distribution and severity of coronary artery disease among patients undergoing coronary artery bypass surgery in Northern Finland. Thromb Res 108(23): 195-196.

Burt, VL; Whelton, P., Roccella, EJ. (1995). Prevalence of hypertension in the US adult population. Hypertens. 25: 305- 313

Dentali, F., Sironi, AP., Ageno, W., Turato, S., Bonfanti, C., Frattini, F., Crestani, S., Franchini, M. (2012). Non-O blood type is the commonest genetic risk factor for VTE: results from a metaanalysis of the literature. Semin Thromb Hemost. 38:535-548.

Edgren, G., Hjalgrim, H., Rostgaard, K., Norda, R., Wikman, A., Melbye, M., Nyren, O. (2010). Risk of gastric cancer and peptic ulcers in relation to ABO blood type: a cohort study, Am J Epidemiol 172(11): 1280-1285.

use of the preparative ultracentrifuge. Clin Chem 18:499-502.

Kauffmann, F., Frette, C., Pham, QT., Nafissi, S., Bertrand, JP., Oriol, R. (1996). Associations of blood group-related antigens to FEV1, wheezing and asthma, Am J Respir Crit Care Med, 153(1), 1996, 76-82.

Kaur, M. (2012). Blood pressure trends and hyp ertension among rural and urban Jat women of Haryana, India, Coll Anthropol 36(1): 139-144.

Ketch, TR., Turner, SJ., Sacrinty, MT., Lingle, KC., Applegate, RJ., Kutcher, MA., Sane, DC. (2008). ABO blood types: influence on infarct size, procedural characteristics and prognosis. Thromb Res 123(2): 200-205.

Landsteiner, K. (1900). Zur kenntnis der antifermentativen, lytischen und agglutinierenden wirkungendes des blutserums und der lymphe. Zentralbl Bakteriol 27:357-363. 
Lewis MS, Bain BJ, Bates J. Miscellaneous tests. In: Practical Haematology, (10th Edition). Churchill Livingstone, Elsevier. 2011; $10^{\text {th }}$ edn, pp. 600.

Lopez-Virella, MF., Stone, P., Eltis, S., Colwell, JA.(1977). Cholesterol determination in HDL separated by three different methods. Clin Chem 23: 822- 884 .

Lutfullah, AB., Quraishi, N U S., Hanif, A., Khan, B Z., Bukhshi, IM. (Jul. - Sept. 2010). Association of $\mathrm{ABO}$ blood groups and major Ischemic heart disease risk factors. Annals 16 (3): 189-193.

Meade, TW., Cooper, JA., Stirling, Y., Howarth, DJ. (1994). Factor VIII, ABO blood group and the Incidence of ischemic heart diseases. Brit. J. Haematol 88 (3), 601-607

Mitchell, JR.. (1977). An association between ABO blood-group distribution and geographical differences in death-rates. Lancet, 1: 295-297.

National Cholesterol Education Program (NCEP) Expert Panel on Detection, Evaluation, and Treatment of High Blood Cholesterol in Adults (Adult Treatment Panel III), (2003). Third Report of the National Cholesterol Education Program (NCEP) Expert Panel on Detection, Evaluation, and Treatment of High Blood Cholesterol in Adults (Adult Treatment Panel III) final report. Circulation 106: 3143-3421.

Nydegger, UE., Wuillemin, WA., Julmy, F., Meyer, BJ., Carrel, TP. (2003). Association of ABO histo-blood group B allele with myocardial infarction. Eur J Immunogenet 30:201-206.

Risch, HA., Lu, L., Wang, J., Zhang, W., Ni, Q., Gao, Y., Yu, H. (2013). ABO Blood Group and Risk of Pancreatic Cancer: A Study in Shanghai and Meta-Analysis, Am J Epidemiol 177(12): 1326-1337.
Saha, N., Toh, CC., Ghosh, MB. (1973). Genetic association in myocardial infarction. Ethnicity; ABO, Rh, Lea, Xga blood groups, G6PD deficiency and abonormal haemoglobins. J Med Genet 10:340-45.

Sari, I., Ozer, O., Davutoglu, V., Gorgulu, S., Eren, M., Aksoy, M. (2008). ABO blood group distribution and major cardiovascular risk factors in patients with acute Myocardial Infarction. Blood Coagul Fibrinol 19 (3): 231-234.

Skaik, YA. (2009). ABO Blood Groups and myocardial infarction among Palestinians.Annals of Cardiac Anaesthesia 12 (2):173-174

Stakisaitis, D., Maksvytis, A., Benetis, R., Viikmaa, M. (2002). Coronary atherosclerosis and blood groups of ABO system in women. Medicina (Kaunas). 38: 230-235.

Tarjan, Z., Tonelli, M., Duba, J., Zorandi, A. (1995). Correlation between $\mathrm{ABO}$ and $\mathrm{Rh}$ blood group: Serum Cholesterol and Ischemic Heart Disease in Patients undergoing Coronarography, Orv Hetil (Hungary) 136 (15): 1767-1769.

Tietz NW. (1995). Clinical Guide to Laboratory Tests. 3nd edition, Philadelphia, USA: W.B. Saunders Company.

Trinder, P. (1969). The principle of assay for enzymatic determination of cholesterol. Ann Clin Biochem, 6: 24.

Whincup, PH., Cook, DG., Phillips, AN., Shaper, A. G. (1990). ABO blood group and ischaemic heart disease in British men. Arch Brit Med J 300: 1679-1682.

Wong, FL., Kodama, K., Sasaki, H., Yamada, M., Hamilton, HB. (1992). Longitudinal study of the association between $\mathrm{ABO}$ phenotype and total serum cholesterol level in a Japanese cohort. Genet Epidemiol 9: 405-418. 